\title{
Determination of the grapevine virome by high-throughput sequencing and grapevine viruses detection in Serra Gaúcha, Brazil
}

\author{
Thor Vinícius Martins Fajardo ${ }^{*} \mathbb{D}$, Airton Alexandre Bertocchi ${ }^{2}$, Osmar Nickel ${ }^{l}$
}

$10.1590 / 0034-737 X 202067020010$

\begin{abstract}
Among grapevine (Vitis spp.) pathogens, viruses stand out, considering that this fruit plant is broadly susceptible to them and that they cause several diseases, reducing quality and yield of grape production. However, detecting and identifying viral infections in grapevines can be challenging. The objectives of this study were to detect grapevine viral pathogens by high-throughput sequencing (HTS) and identify grapevine viruses associated with plant propagation material from different origins. A comprehensive picture of a vine exhibiting virus-related symptoms was generated. The detected virome included four different pathogens and their variants. In addition, the incidence of seven viral pathogens was determined in samples collected in three vineyards of the main grape-growing region of Brazil. It is suggested that the observed infections could be related to the technological level of the production system adopted by these grape growers.
\end{abstract}

Keywords: RT-qPCR; HTS; NGS; Vitis; indexing; survey.

\section{INTRODUCTION}

The sanitary status of the grapevine (Vitis spp.) is determinant for growth, productivity of the grapevine and the quality of grapes. Parameters such yield and grape quality are heavily affected by viral pathogens. As a consequence, adequate diagnosis and identification of viruses is of fundamental relevance for efficient plant protection (Zherdev et al., 2018).

Grapevine leafroll disease (GLRD) is widespread worldwide wherever grapes are grown and it is known as the most damaging infectious disfunction of grapevines. The disease is often caused by a mixed infection of a complex of several leafroll-causing virus species (family Closteroviridae), being Grapevine leafroll-associated virus-3 (GLRaV-3), genus Ampelovirus, the most prevalent and widely spread (Naidu et al., 2015). Grapevine rugose wood disease (GRWD) is a complex disease that occurs worldwide which is associated with several syndromes including rupestris stem pitting; kober stem grooving; corky bark and LN33 stem grooving. Among the viral pathogens associated with the disease, Grapevine rupestris stem pitting-associated virus (GRSPaV) and Grapevine viruses $A$ and $B$ (GVA and GVB), genera Foveavirus and Vitivirus, respectively, stand out as causative agents (family Betaflexiviridae) (Basso et al., 2017). So far, Grapevine yellow speckle viroid 1 (GYSVd1), Hop stunt viroid (HSVd), and Citrus exocortis viroid (CEVd) have been detected in diseased grapevines in Brazil (Fajardo et al., 2016; 2018). These viroids are worldwide distributed, infecting a large number of host species besides vine, except for GYSVd-1, which is restricted to grapevines. Finally, Grapevine fleck virus $(\mathrm{GFkV})$ is a phloem-limited, positive-sense, single-stranded RNA virus belonging to the genus Maculavirus, family Tymoviridae, present worldwide and known to be associated with the grapevine fleck disease complex (Fajardo et al., 2017b).

The recent improvements of nucleotide sequencing technologies, such as high-throughput sequencing (HTS), has generated great advances in prospecting for viral pathogens, including the discovery of novel viruses infecting plants. Its main advantages are sequencing

Submitted on October $7^{\text {th }}, 2019$ and accepted on December $11^{\text {th }}, 2019$

'Embrapa Uva e Vinho, Bento Gonçalves, Rio Grande do Sul, Brazil. thor.fajardo@embrapa.br; osmar.nickel@embrapa.br ${ }^{2}$ Universidade Estadual do Rio Grande do Sul, Bento Gonçalves, Rio Grande do Sul, Brazil. airtonalebertocchi@ gmail.com "Corresponding author: thor.fajardo@embrapa.br 
millions of reads in a random massive parallel sequencing strategy; to allow the identification of the viruses infecting the host, including divergent viral variants, which could be more difficult to be detected using standard molecular techniques and, disease complexes; the capacity to promote detection of pathogens that are not preestablished targets of indexing and also of those pathogens whose nucleotide sequences are not available (Fajardo et al., 2017b). The advent of HTS represents a great advancement for the study of grapevine viruses, given the characteristic features of these agents in terms of the difficult transmission of most of them to herbaceous plants, their usually very low titers in grapevines, and the difficulties in processing grapevine woody tissues (Saldarelli et al., 2017). The implementation of HTS for diagnosis, that does not require prior information on the virus, is important for the sensitivity, comprehensiveness and reliability features attributed to the results.

The determination of virus identity that infect grapevines is important for etiology, but also because this achievement will result in more detailed knowledge of the pathogen and therefore more precise and accurate detection methods can be developed and adopted. In this context, many grapevine viruses have been already biologically, serologically and molecularly characterized in Brazil (Basso et al., 2017). Grapevine disease control is inevitably based on determining the sanitary status of the vines. Since many grapevine viruses are transmitted by several types of vectors (nematodes, mealybugs, mites, among others), the new vineyards should be established with certified plant propagation material to prevent against disease spread. Since it is impossible to restore plant health of a virus-infected plant in the field, prophylactic measures such as the use of healthy plant propagation material during planting has outstanding importance (Basso et al., 2017). The objectives of this study were to detect grapevine viruses by high-throughput sequencing (HTS) and identify grapevine viruses associated with plant propagation material of different origins.

\section{MATERIALAND METHODS}

\section{HTS}

To achieve a more comprehensive picture of the hybrid grapevine cv. BRS Núbia virome, an adult plant exhibiting severe virus-related symptoms i.e. down rolling and reddening of leaves with the green main veins and coriaceous leaves in early fall (Figure 1), maintained in the experimental field at Embrapa Grape \& Wine in Bento Gonçalves, RS, Brazil, was analysed by high-throughput sequencing (HTS).

Double-stranded RNAs (dsRNA) were extracted from $30 \mathrm{~g}$ of bark scrapings of mature grapevine canes. The resulting supernatant (nucleic acid solution) was enriched for dsRNA using Whatman CF11 cellulose affinity purification (chromatography) (Valverde et al., 1990). The complementary DNA library was constructed utilizing TruSeq Stranded mRNA kits (Illumina, USA) according to the manufacturer's instructions. After quantification and qualification during the quality control step, the sample library was sequenced on the BGISEQ-500 platform (pairedend reads). Sequencing was performed using a service from Beijing Genomics Institute (BGI, China). CLC Genomics Workbench v. 8.5.1 (CLC Bio, Qiagen, USA) was used for quality trimming and de novo contig assembly of the reads. All contigs were annotated by BLASTn and BLASTx (http://www.ncbi.nlm.nih.gov/ blast) against the nr or protein GenBank databases using a cut-off e-value of $10^{-4}$.

Nucleotide sequences obtained by HTS were deposited in the GenBank and aligned with the reference sequences of the viruses as well as with some of the most similar sequences among the homologous viruses available in the GenBank using the NCBI's Blastn program (https://blast.ncbi.nlm.nih.gov/Blast.cgi). The GenBank accession codes of the nucleotide sequences of the isolates used for the homology analysis are shown in Table 1 and Figure 2. Multiple nucleotide (nt) sequence alignments were performed using ClustalX 2.1 program. Phylogenetic relationships were determined from the aligned sequences by the neighbor-joining (NJ) method using Kimura 2-parameter method with gamma distribution (G) and 1,000 bootstrap replications implemented in Molecular Evolutionary Genetics Analysis (MEGA 7.0.21) software package.

\section{Virus survey}

A total of thirty-six grapevine plants cvs. Niágara Branca, Chardonnay and BRS Carmem, exhibiting virus symptoms or symptomless (Figure 1), were analysed for seven pathogens [Grapevine leafroll-associated virus 3 (GLRaV-3), Grapevine virus A (GVA), Grapevine virus B (GVB), Grapevine fleck virus (GFkV), Grapevine rupestris stem pitting-associated virus (GRSPaV), Grapevine leafroll-associated virus $4(\mathrm{GLRaV}-4)$ and Grapevine yellow speckle viroid 1 (GYSVd-1)] by realtime RT-PCR (RT-qPCR) (Dubiela et al., 2013) and additionally by conventional RT-PCR for Hop stunt viroid (HSVd). Twelve samples per vineyard were analysed: two asymptomatic samples, two samples with virus-like symptoms and eight randomly collected samples. The complementary information about the three sampled vineyards (V) were: V1: scion cultivar (cv.) Niágara Branca (17 years old), undefined rootstock; V2: cv. Chardonnay (one year old), rootstock cv. 1103P, and V3: cv. BRS Carmem (two years old), rootstock cv. 1103P, 
respectively in pergola, trellis and pergola training systems. The three areas sampled in municipalities of Serra Gaúcha, Rio Grande do Sul State, Brazil, in March 2019 were: vineyard 1 - Farroupilha; vineyard 2 - Santa Tereza and vineyard 3 - Pinto Bandeira.

\section{Real time and conventional RT-PCR}

Total RNA extractions were performed using the adsorption of nucleic acids on silica particles from $1 \mathrm{~g}$ of petioles or veins of leaves or scrapings of mature stems, grinding plant tissues in liquid nitrogen (Dubiela et al., 2013). RT-qPCR reactions (one step RT-qPCR) were carried out in 96-well plates using the thermocycler StepOnePlus Real-Time PCR System (Applied Biosystems) and the kit TaqMan Fast Virus 1-Step Master Mix (Applied Biosystems) following the manufacturer's recommendations and as described by Fajardo et al. (2016). The reaction data were analysed as presence/ absence assays and graphically, using the StepOne Software v2.3 (Applied Biosystems), by determining the $\mathrm{Cq}$ (quantification cycle). Specific primers and TaqMan TAMRA probes used for viruses detections by RT-qPCR were previously described (Osman et al., 2007; Dubiela et al., 2013).

The presence of all viruses/viroids identified by HTS was confirmed in the cv. BRS Núbia sample by conventional RT-PCR just as performed for HSVd detection in the field survey. The RT-PCR was carried out using OneStep RT-PCR kit (Qiagen) and reactions were performed according to the manufacturer with $4 \mu \mathrm{L}$ (ca. $400 \mathrm{ng}$ ) of total RNA. Specific primers for GLRaV-3, GRSPaV, GYSVd-1 and HSVd used for pathogen detections by RT-PCR were previously described (Basso et al., 2010; Fajardo et al., 2016; 2018).

\section{RESULTS AND DISCUSSION}

\section{HTS}

Four pathogens [Grapevine leafroll-associated virus 3 (GLRaV-3), Grapevine rupestris stem pitting-associated virus (GRSPaV), Grapevine yellow speckle viroid 1
(GYSVd-1) and Hop stunt viroid (HSVd)] were disclosed by HTS in cv. BRS Núbia exhibiting virus-like symptoms thus confirming the broad capacity of the technique in detecting pathogens from different taxa in a concurrent infection. This complex symptomatology hampered the visual diagnosis. The presence of these pathogens infecting the analysed plant material was confirmed by conventional RT-PCR. Complete or near-complete genomes corresponding to these pathogens were obtained and deposited at GenBank: GLRaV-3 complete genome, GLRaV-3.NUB-BR isolate, 18498 nucleotides (nt), MK804765; GRSPaV, three distinct isolates corresponding to nearly complete genomes, lacking only 30-36 nucleotides in the translatable portion of the genome (5, ORF1 - coding for replicase): NUB1-BR, $8627 \mathrm{nt}$, MK804766; NUB2-BR, 8633 nt, MK804767 and NUB3-BR, 8665 nt, MK804768; GYSVd-1 complete genome, GYSV1.NUB-BR isolate, 366 nt, MK804769 and HSVd complete genome, HSV.NUB-BR isolate, 298 nt, MK804770. Refering to the virus populations in grapevines, Saldarelli et al. (2017) considered the "concept of a virome" more appropriate to characterize the presence of multiple infections as a result of viticultural procedures that lead to accumulation of virus and viroid pathogens in connection with the long-term exposure of the grapevine to these pathogens.

According to Saldarelli et al. (2017), grapevine plants harbor a core assembly of viruses and viroids which they call the "background" virome, consisting of GRSPaV, HSVd, GYSVd-1 as well as some viral species belonging to the genera Maculavirus and Marafivirus. As a result, these authors consider a "virus-free" grapevine as an inappropriate naming. In this perspective, the presence of this core group of pathogens, although probably involved as co-determinants in a synergistic system, is irrelevant and not determinant of disease etiology. Disease itself is triggered by the really damaging viral species that disrupt the balance of the "natural" virome present in the plant. In fact, previous surveys with samples of grapevines collected in Brazil detected high incidences of these "background" viruses: up to $80 \%$ GRSPaV (Catarino et
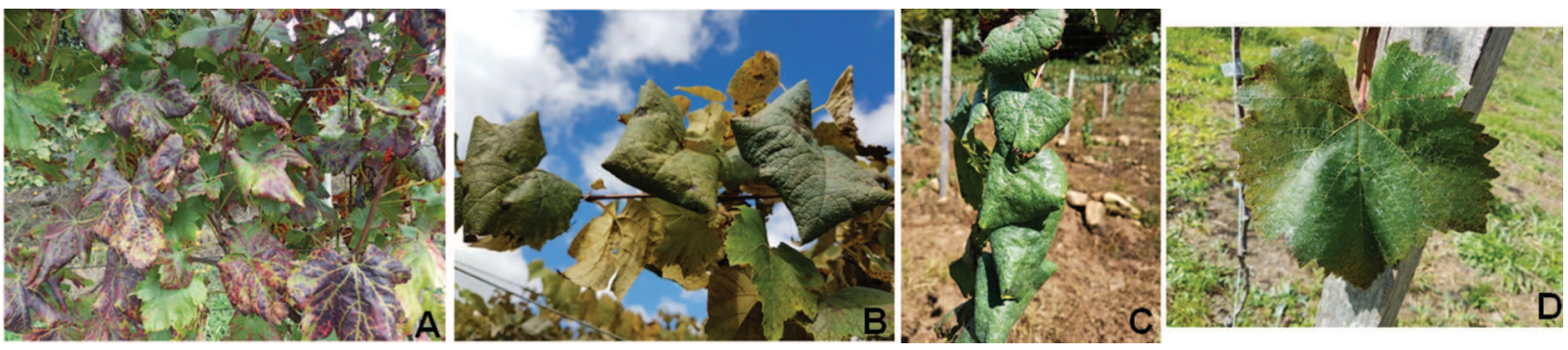

Figure 1: Grapevine samples collected and evaluated: (a) hybrid grapevine cv. BRS Núbia exhibiting virus-related symptoms; symptomatic vines (b) cv. Niágara Branca and (c) cv. Chardonnay and, (d) asymptomatic cv. BRS Carmem. 
Table 1: Information about sequences of GLRaV-3, GRSPaV, GYSVd-1 and HSVd included in the study and available in GenBank and nucleotide identities among them

\begin{tabular}{|c|c|c|c|c|c|}
\hline $\begin{array}{l}\text { Virus species } \\
\text { and Brazilian isolates }\end{array}$ & Isolate & Country & $\begin{array}{l}\text { Genome length } \\
\text { (nucleotide) }\end{array}$ & $\begin{array}{c}\text { GenBank } \\
\text { accessions } \\
\text { (genome) }\end{array}$ & $\begin{array}{c}\text { Genome } \\
\text { nucleotide identity } \\
\text { between isolates }\end{array}$ \\
\hline \multirow{8}{*}{$\begin{array}{l}\text { GLRaV-3 } \\
\text { (GLRaV-3.NUB-BR) }\end{array}$} & Kat255 & USA & 18498 & MH521108 & $99.5 \%$ \\
\hline & WA-MR & USA & 18498 & GU983863 & $99.4 \%$ \\
\hline & LN3204 & USA & 18498 & MH521112 & $99.4 \%$ \\
\hline & GLRaV3-ID46 & USA & 18498 & MH796135 & $99.4 \%$ \\
\hline & $3138-07$ & Canada & 18498 & JX559645 & $99.4 \%$ \\
\hline & Bla223 & USA & 18498 & MH521090 & $99.4 \%$ \\
\hline & Cha106 & USA & 18497 & MH521093 & $99.3 \%$ \\
\hline & reference sequence & USA & 17919 & NC_004667 & $97.8 \%$ \\
\hline \multirow{10}{*}{ GRSPaV (NUB1-BR) } & 35 clone 4 & France & 8728 & MG938308 & $98.4 \%$ \\
\hline & $1050-02$ & Canada & 8716 & JX513892 & $98.4 \%$ \\
\hline & AMCF clone 2 & France & 8735 & MG938310 & $98.3 \%$ \\
\hline & P70 & France & 8726 & MG925334 & $98.2 \%$ \\
\hline & 34 clone 2 & France & 8691 & MG938304 & $98.2 \%$ \\
\hline & - & USA & 8725 & AF026278 & $98.1 \%$ \\
\hline & - & USA & 8744 & AF057136 & $98.1 \%$ \\
\hline & reference sequence & USA & 8744 & NC_001948 & $98.1 \%$ \\
\hline & NUB2-BR & Brazil & 8633 & MK804767 & $79.7 \%$ \\
\hline & NUB3-BR & Brazil & 8665 & MK804768 & $79.5 \%$ \\
\hline \multirow{9}{*}{ GRSPaV (NUB2-BR) } & Clone 2 & France & 8725 & MG925335 & $92.3 \%$ \\
\hline & LSL & China & 8754 & KR054735 & $92.3 \%$ \\
\hline & 35 clone 2 & France & 8676 & MG938306 & $92.0 \%$ \\
\hline & EVC42 & France & 8716 & MG938332 & $80.1 \%$ \\
\hline & EVB47 & France & 8726 & MG938328 & $80.1 \%$ \\
\hline & EVC60 & France & 8713 & MG938340 & $80.1 \%$ \\
\hline & EVC53 & France & 8716 & MG938335 & $80.1 \%$ \\
\hline & reference sequence & USA & 8744 & NC_001948 & $79.7 \%$ \\
\hline & NUB3-BR & Brazil & 8665 & MK804768 & $79.0 \%$ \\
\hline \multirow{8}{*}{ GRSPaV (NUB3-BR) } & VD-102 & Croatia & 8706 & MF979534 & $97.7 \%$ \\
\hline & 34 clone 1 & France & 8706 & MG938303 & $93.7 \%$ \\
\hline & strain Syrah & USA & 8742 & AY368590 & $93.3 \%$ \\
\hline & SWTi clone 2 & France & 8723 & KX035000 & $92.5 \%$ \\
\hline & SWT6 clone 1 & France & 8741 & KX034997 & $92.5 \%$ \\
\hline & MBE10 clone 2 & France & 8737 & MG938343 & $92.5 \%$ \\
\hline & SWT2 clone 2 & France & 8741 & KX034991 & $92.4 \%$ \\
\hline & reference sequence & USA & 8744 & NC_001948 & $79.7 \%$ \\
\hline \multirow{8}{*}{ GYSVd-1(GYSV1.NUB-BR) } & Cari 2-4 & Tunisia & 366 & AF462162 & $92.8 \%$ \\
\hline & UDSV1-4 & Nigeria & 366 & MF576400 & $92.6 \%$ \\
\hline & VI-BR & Brazil & 366 & KU668664 & $92.5 \%$ \\
\hline & DgSV1-8 & Nigeria & 366 & MF576407 & $92.3 \%$ \\
\hline & Cari 1-1 & Tunisia & 366 & AF462167 & $92.3 \%$ \\
\hline & variant VIII & - & 366 & X87922 & $92.3 \%$ \\
\hline & Cari 2-5 & Tunisia & 367 & AF462161 & $92.3 \%$ \\
\hline & reference sequence & - & 366 & NC_001920 & $83.0 \%$ \\
\hline \multirow{8}{*}{ HSVd (HSV.NUB-BR) } & VL-TC & Brazil & 298 & MG431974 & $99.3 \%$ \\
\hline & VV-CF & Brazil & 298 & MF774875 & $99.3 \%$ \\
\hline & VV-CG & Brazil & 298 & MF774872 & $99.3 \%$ \\
\hline & VV-IT & Brazil & 298 & MF774871 & $99.3 \%$ \\
\hline & VV-CS & Brazil & 298 & MF774862 & $99.3 \%$ \\
\hline & cultivar Riesling & - & 298 & X06873 & $99.3 \%$ \\
\hline & HSVd.PN.12 & Hungary & 298 & GQ995466 & $99.0 \%$ \\
\hline & reference sequence & - & 302 & NC_001351 & $94.4 \%$ \\
\hline
\end{tabular}


al., 2015), 71.4\% GYSVd-1 (Fajardo et al., 2016) and, 94\% HSVd (Fajardo et al., 2018). In the present study, the "background" virome (GRSPaV, HSVd and GYSVd-1) and a damaging virus (GLRaV-3) were detected, of which the latter could be the causal agent of the observed leafroll symptoms in the sampled vine (Figure 1). Thus, we conclude, our results are in agreement with the above information.

The highest nucleotide identities among the studied Brazilian virus and viroid isolates and some homologous isolates retrieved from GenBank ranged from $92.0 \%$ to $99.5 \%$ allowing unambiguous identification of the pathogens that were infecting the grapevine cv. BRS Núbia (Table 1). In addition, the phylogenetic analysis of nearly complete genomes (Figure 2) highlighted the identification of three widely variable isolates of GRSPaV showing $79.0 \%$ to $79.7 \%$ nucleotide identities among them (Table 1). Considering that the capsid protein gene is usually conserved because it encodes a structural protein, genetic variability studies based only on this gene can not allow to fully explore the existing variability between isolates (Moura et al., 2018). Fajardo et al. (2017a) reported the occurrence of three molecular variants of GRSPaV infecting different grapevine genotypes in Brazil based on the analysis of the viral capsid protein nucleotide sequences. On the other hand the present study demonstrates, based on partial genome variabilities, the occurrence of three different GRSPaV isolates in one single plant whereas Fajardo et al. (2017a)

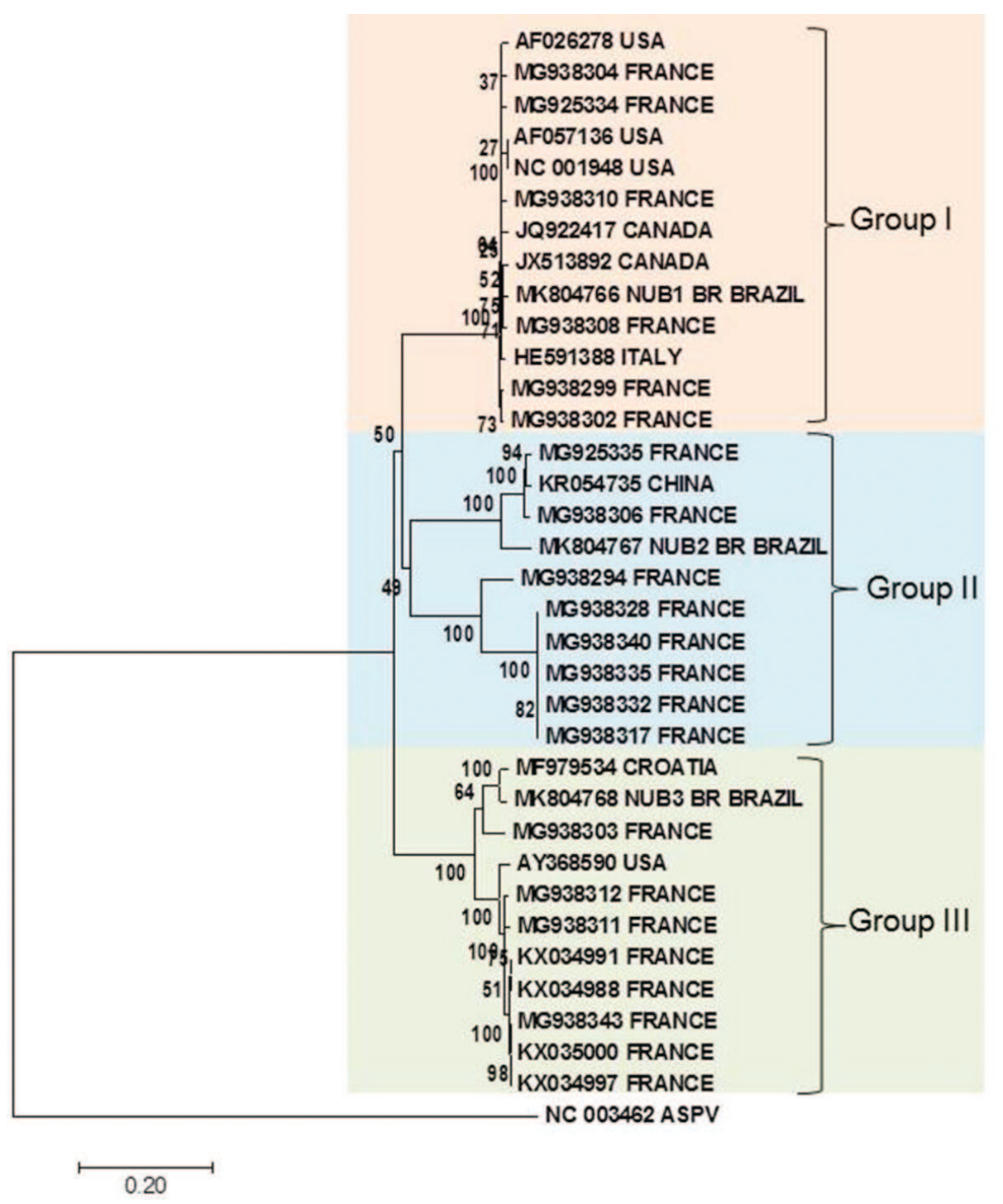

Figure 2: Phylogenetic relationship among GRSPaV isolates based on the multiple alignment of the complete genome or nearcomplete genome nucleotide sequences of three isolates from Brazil and other isolates retrieved from the GenBank. The tree was constructed by the neighbor-joining method using Kimura 2-parameter with gamma distribution $(\mathrm{G})$ and 1,000 bootstrap replications implemented using MEGA 7.0.21 software package. Acessions of GRSPaV and origins were included according to the GenBank. Phylogenetic clusters (groups) are indicated. Apple stem pitting virus (ASPV) was used as outgroup. Bar: number of nucleotide substitutions per site. 
demonstrated the presence of up two different isolates (variants) in the same plant (genotype). The occurrence of different isolates, variant sequences, strains or groups of GLRaV-3, GYSVd-1 and HSVd infecting grapevines was previously reported (Fajardo et al., 2016, 2017b, 2018, Moura et al., 2018). This study may contribute to expand the understanding of the variability and diversity of these viral/ viroidal species in Brazil, although this was not specifically the focus of this study, and to elucidate the meaning of symptom expression considering the grapevine genotype and the pathogens/strains present in the pathosystem. Another contribution of this study was that by determining the nucleotide sequences of local viral isolates, diagnostic tools can be customized to detect these pathogens, e.g. RT-PCR primers or probes could be designed specifically for the detection of these isolates, thus increasing probability of reliable diagnosis.

HTS allowed obtaining of complete or near-complete genomes of four viral and viroidal pathogens, including different isolates in a single sequencing step. The application of HTS, for this aim, overcomes the eventual difficulties of conventional RT-PCR amplifications of several DNA fragments, which require extensive cloning and sequencing of recombinant clones to obtain complete viral genomes (Souza et al., 2017). In this study, the complete translatable nucleotide sequences of viruses such as GLRaV-3, one of the largest genomes among plant-infecting viruses, have been obtained. The high contents of closteroviruses usually found in metadata produced from dsRNA could be determined by the fact that many RNA viruses, as closteroviruses, show a higher tendency to accumulate double-stranded replicative intermediate forms of RNA (Saldarelli et al., 2017) as compared to other viruses.

The restriction on the use of a particular molecular diagnostic test lies on the fact that it is only directed to the detection of pathogens with prior known nucleotide sequences and to specific pathogens that would be predefined reaction targets. This makes it impossible to detect pathogens with unknown nucleotide sequences or genomes, pathogens with sequences that vary from the standard isolate or that are not predefined detection targets. These three limitations are overcome by HTS as an investigation tool (Saldarelli et al., 2017) as also demonstrated in this study. As the grapevine can be simultaneously infected by several viral pathogens, the expression of symptoms would not be elucidative, and thus, the selection of probable pathogens that would need to be tested as etiological agents of the disease would become an impaired task (Basso et al., 2017). Therefore, HTS is an extremely relevant interesting option to apply since it allows to determine the full range of pathogens present in a diseased plant (Villamor et al., 2019).
Additionally, the information generated with this technique can be used to define more efficient strategies for virus control and management.

\section{Virus survey}

The TaqMan RT-qPCR and conventional RT-PCR were sensitive, specific and reliable tests to evaluate the presence of the six viruses and two viroids in a limited survey of field-sampled vines. The average rates of viral and viroidal infections considering 12 samples/vineyard were $61.4 \%$ (V1), 37.4\% (V2) and 53.1\% (V3). The observed incidences $(\%)$ of each pathogen in each vineyard (V) were as follows: V1: 75\% (GLRaV-3), 66.6\% (GVA), 33.3\% (GVB), 91.6\% (GFkV), 66.6\% (GRSPaV), 91.6\% (GYSVd-1), $66.6 \%$ (HSVd); V2: $25 \%$ (GLRaV-3), 16.6\% (GVA), $0 \%$ (GVB), 16.6\% (GFkV), 75\% (GRSPaV), 91.6\% (GYSVd-1), 75\% (HSVd) and, V3: 75\% (GLRaV-3), 33.3\% (GVA), 50\% (GVB), 100\% (GFkV), 0\% (GRSPaV), 100\% (GYSVd-1), $66.6 \%$ (HSVd). None of the evaluated samples were infected with GLRaV-4. These results confirm other results reporting high incidence of these pathogens in vineyards evaluated in other grape-growing regions of Brazil (Catarino et al., 2015; Moura et al., 2018). Probably, the infection levels found are determining detrimental effects in the yield potential and product quality (reductions in total soluble solid content and berry color intensity) of the three evaluated cultivars and vineyards as reported when healthy vines were compared to those with viral infections (Mannini \& Digiaro, 2017), although this issue was not evaluated in this study.

Multiple viral and viroidal infections were frequent. Infection rates by pathogens were increasing considering the origin of the grafted-vine cuttings (V2: imported grafted-vine cuttings with official certification; V3: graftedvine cuttings purchased in Brazilian commercial nursery that adopts certain practices of phytosanitary improvement, and V1: grafted-vine cuttings produced by the grape grower with his own plant propagation material, without any certification or without adoption of cultural practices that could significantly contribute to the improvement of the vineyard phytosanitary condition) suggesting that the origins of the grafted-vine cuttings may have influenced the determined virus incidences. In other words, the incidence of viruses would have varied according to the level of technology adoption by the grape growers, specifically regarding the phytosanitary quality of the grafted-vine cuttings used for the establishment of vineyards. This is an inference because the evaluated plants had been in the field for different time after planting and in this condition could have suffered viral reinfection to a greater or lesser extent. Also, the viral incidence increased with the age of vineyards suggesting transmission of some evaluated pathogens 
by vectors, for $e . g$. mealybugs and scale insects that can transmit GLRaV-3, GVA and GVB; mechanical transmission occurrence (in the case of viroids) or dissemination through vegetative propagation using infected material (in the case of viruses that do not have vectors: GFkV and GRSPaV) (Catarino et al., 2015; Fajardo et al., 2016). These possibilities could be acting in the evaluated vineyards over time. Asymptomatic samples [in particular American grapevine (V. labrusca) cv. Niágara Branca or hybrid cv. BRS Carmem] were also infected similarly to symptomatic vinifera vines. Thus, there was no evident difference in viral infection incidences considering asymptomatic and symptomatic samples (data not shown). This is relevant because asymptomatic plants can function as indistinguishable viral inoculum source and even they may have their quality and yield of production negatively affected by viral infection, but usually at lower levels than those verified in symptomatic plants (Basso et al., 2010; Mannini \& Digiaro, 2017). Taken together, the information generated on viral incidence, even though limited, could be useful for the management of viruses in the evaluated regions, avoiding further dissemination and dispersion.

The HTS is the most sensitive and comprehensive diagnostic tool for the study of undiagnosed viral diseases presently available; it is very cost effective compared to the traditional detection methods and allows to investigate viral genome diversity, virus-host interaction and virus epidemiology (Saldarelli et al., 2017; Villamor et al., 2019). Also, the determination of the pathogen incidence in certain regions represents relevant information that enables the proposition of more efficient management and control techniques, including the determination of the actual phytosanitary status of grafted-vine cuttings used by growers for the establishment of new vineyards.

\section{CONCLUSIONS}

The use of high-throughput sequencing to determine the total viral content of a sample resulted in the identification of a complex disease, including viruses, viroids and their strains in the analysed grapevine. Thus, HTS was a very sensitive, comprehensive and accurate diagnostic tool, allowing to investigate thoroughly grapevine viral genome diversity and constituted a reliable tool to assess the phytosanitary status, overcoming some limitations encountered in grapevine virus diagnosis.

The phytosanitary status determination which consisted of identification of viral pathogens associated with grapevines in vineyards contributed to understand some aspects related to the disease (e.g. virus transmission through vegetative propagation of infected grapevines, virus epidemiology). In this perspective it is an appropriate approach to target virus control and management.

\section{ACKNOWLEDGEMENTS}

To Empresa Brasileira de Pesquisa Agropecuária (Embrapa) for the financial support to this research (Projects 02.13.14.002.00.00 and 22.16.04.035.00.00) and Conselho Nacional de Desenvolvimento Científico e Tecnológico (CNPq) for the student scholarship (AAB). To Marcos F. Vanni for technical support and to Thierry Candresse (INRAE - Université de Bordeaux, France) for his kind help with bioinformatic analysis of HTS data. The authors inform that there is no conflict of interests in carrying out the research and publishing this manuscript.

\section{REFERENCES}

Basso MF, Fajardo TVM, Eiras M, Ayub RA \& Nickel O (2010) Detecção e identificação molecular de vírus associados a videiras sintomáticas e assintomáticas. Ciência Rural, 40:2249-2255.

Basso MF, Fajardo TVM \& Saldarelli P (2017) Grapevine virus diseases: economic impact and current advances in viral prospection and management. Revista Brasileira de Fruticultura, 39:e-411.

Catarino AM, Fajardo TVM, Pio-Ribeiro G, Eiras M \& Nickel O (2015) Incidência de vírus em videiras no Nordeste brasileiro e caracterização molecular parcial de isolados virais locais. Ciência Rural, 45:379-385.

Dubiela CR, Fajardo TVM, Souto ER, Nickel O, Eiras M \& Revers LF (2013) Simultaneous detection of Brazilian isolates of grapevine viruses by TaqMan real-time RT-PCR. Tropical Plant Pathology, 38:158-165.

Fajardo TVM, Eiras M \& Nickel O (2016) Detection and molecular characterization of Grapevine yellow speckle viroid 1 isolates infecting grapevines in Brazil. Tropical Plant Pathology, 41:246-253.

Fajardo TVM, Eiras M \& Nickel O (2018) First report of Hop stunt viroid infecting Vitis gigas, V. flexuosa and Ampelopsis heterophylla. Australasian Plant Disease Notes, 13:3.

Fajardo TVM, Kin AC \& Nickel O (2017a) Molecular variants of Grapevine rupestris stem pitting-associated virus infecting grapevines (Vitis spp.) in Brazil. Ciência Rural, 47:e20161113.

Fajardo TVM, Silva FN, Eiras M \& Nickel O (2017b) Highthroughput sequencing applied for the identification of viruses infecting grapevines in Brazil and genetic variability analysis. Tropical Plant Pathology, 42:250-260.

Mannini F \& Digiaro M (2017) The effects of viruses and viral diseases on grapes and wine. In: Meng B, Martelli GP, Golino DA \& Fuchs M (Eds.) Grapevine Viruses: Molecular Biology, Diagnostics and Management. Cham, Springer. p.453-482.

Moura CJM, Fajardo TVM, Eiras M, Silva FN \& Nickel O (2018) Molecular characterization of GSyV-1 and GLRaV-3 and prevalence of grapevine viruses in a grape-growing area. Scientia Agricola, 75:43-51.

Naidu RA, Maree HJ \& Burger JT (2015) Grapevine leafroll disease and associated viruses: A unique pathosystem. Annual Review of Phytopathology, 53:613-634.

Osman F, Leutenegger C, Golino D \& Rowhani A (2007) Realtime RT-PCR (TaqMan) assays for the detection of Grapevine leafroll associated viruses 1-5 and 9. Journal of Virological Methods, 141:22-29. 
Saldarelli P, Giampetruzzi A, Maree HJ \& Al Rwahnih M (2017) High-throughput sequencing: Advantages beyond virus identification. In: Meng B, Martelli GP, Golino DA \& Fuchs M (Eds.) Grapevine Viruses: Molecular Biology, Diagnostics and Management. Cham, Springer. p.625-642.

Souza EB, Nickel O, Fajardo TVM, Silva JMF \& Barros DR (2017) Biological and molecular characterization of two Brazilian isolates of Apple stem grooving virus. Tropical Plant Pathology, 42:391-396.
Valverde RA, Nameth ST \& Jordan RL (1990) Analysis of doublestranded RNA for plant virus diagnosis. Plant Disease, 74:255258.

Villamor DEV, Ho T, Al Rwahnih M, Martin RR \& Tzanetakis IE (2019) High throughput sequencing for plant virus detection and discovery. Phytopathology, 109:716-725.

Zherdev AV, Vinogradova SV, Byzova NA, Porotikova EV, Kamionskaya AM \& Dzantiev BB (2018) Methods for the diagnosis of grapevine viral infections: A review. Agriculture, $8: 195$. 